Faculty of Law, Matej Bel University in Banská

Bystrica, Slovakia

DOI: $10.13166 / \mathrm{JMS} / 95062$

JOURNAL OF MODERN

anna.schneiderova@umb.sk

RÓBERT JÁGER

Faculty of Law, Matej Bel University in Banská

Bystrica, Slovakia

robert.jager@umb.sk

\title{
TERMINOLOGICAL AND HISTORICAL BACKGROUNDS OF THE CRIMINAL LAW DEVELOPMENT: FROM THE PRIVATE LAW SECTOR TO THE PUBLIC LAW SECTOR
}

\begin{abstract}
The paper describes the development of criminal law as the originally private law sector and points to changes that ultimately have changed the nature of criminal law so that it is now considered to be a public law sector. Criminal law during the period of the high and late Middle Ages on the territory of Slovakia had the character of a public law sector. Recovery after committing the crime was left to the injured person or his family. The relationship between the injured (or his survivors) and the perpetrator was largely private in nature. The state originally did not interfere or interfere only at a minimum with this relationship. Only in the course of time has this element of a largely private legal relationship been also given a public-law element, only in the age of Modern Times the criminal-law relations had the character of public law. This article describes the changes that have occurred in the course of time in the area of criminal law, the ways of punishment, and the changes which have led to the transformation of criminal law into the public law sector.
\end{abstract}

KEYWORDS: riminal law, history, private law, public law, terminology. 


\section{INTRODUCTION}

Criminal law is currently considered as the public law sector. The recognition of the public law nature of criminal law is so obvious to us that the idea of the possibility of partial privatization of the nature of some criminal law institutes seems strange to us. However, if we look at the deepest past of the development of criminal law in our territory, we find that criminal law (however, not called so at that time) was predominantly private.

In the Slovak Republic, a grant project titled Privatization of Criminal Law - the substantive, procedural, criminological, organizational and technical aspects are currently being dealt with. One of the objectives of this project is to point out the possibility of a change in the almost exclusively public-law nature of most criminal law institutes in this sector of our law. Project leaders are heading towards a direction that can be seen as a breakthrough in terms of Central Europe, but not entirely non-existent in the global context. For example, in the USA, they have experience with the existence of private prison facilities since the penultimate decade of the last century. Motivation for the change of the formerly existing prison facilities under the control of the state's public authorities (especially at the federal level) was the overloading of the existing facilities and their economic inefficiency.

Following the pattern of the US, some European countries have also been inspired in the recent past. A "pilot project" on the introduction of private prison facilities can now be seen in the UK, similarly (even to a lesser extent) there is the establishment of a detention facility in Germany. In both countries there are so-called "pilot projects that aim to show the "viability" and justify the existence of such facilities. It is commendable that the European countries in question have taken "a more cautious path" when they intend to test their functioning on a smaller sample of the equipment, observing aspects of introducing such changes not only at the level of the legal but also the broadest impact on the largest area of social or economic relations. It should be emphasized that in these European countries, special attention is also paid to the person placed in the prison facility and the effects of such a private facility on their possible rehabilitation or eventual re-entry into society are also assessed.

Even though in the current European area the introduction of private prison facilities is considered to be a "breakthrough", and its only a gradual 
introduction into practice is correct, the system of the existence of private facilities for imprisonment is not in the history of European countries a novelty. This is mainly determined by the perception and nature of "criminal law" as such in the earliest times of its existence.

\section{HistoricAL BACKGROUND}

In most medieval European countries, criminal law was almost exclusively private in nature. This fact is a consequence of the so called patrimonial nature of the state units of the given period. So called the patrimonial character of the (medieval) states reflects the fact that the period state units were considered patrimony (property) of the sovereign. In particular, the land base of the state was the property of the sovereign, and he "only" granted it to some people for merits, and they were able to grant it to him committed persons. This created a scheme of social relations, at the top of which the monarch himself was the "owner of the state", and under him there was a hierarchically structured system of "vassals", of which the aristocracy was later constituted. The lowest in this social structure of relations of supremacy and subordination were the subjects (or serfs or sometimes slaves) who were assigned to the land and worked on it.

The monarch standing at the top of this structure ruled the state as his "dominium", as his property. Any property "offense" against the object of property belonging to this property substance of the state was considered a "crime" against the property of the sovereign, and was thus punished (Gábriš - Jáger, 2016). In particular, the period attacks on the property of the sovereign have been punished by the state, and these crimes can be regarded as those that we would (in today's language) describe as acts punishable by the public authorities (even though they have attacked the property of the sovereign). In the same group, also "offenses" (or in period language called "attacks") on the person of the sovereign, his family, "familiars", members of the court and other persons associated with him could be included.

The sovereign also performed the function of (supreme) judge over the entire state during that period. The monarch in the oldest period most often did not have one seat, but "wandered" with his court across the country, and where he stopped with his court, the cases were heard. During these stops, besides administering state matters (which also covered the administration 
of his property), he resolved litigation and "condemned" perpetrators of "crimes". The gradual expansion of the territory of the state units of the period, and the gradual increase of the administrative agenda, made it necessary for the sovereign to delegate (among other things) trying and punishment to other persons. Most often, they were entrusted with the exercise of judicial power by a person close to the sovereign. These people first litigated in the name of the sovereign, until with the passage of the time independent judges with their own jurisdiction were created.

An interesting point in the "criminal law" of a given period is that the commission of a criminal offense against the life, health or property of a private person (unrelated to a sovereign) was not necessarily followed by the punishment of the offender by the state from the position of the "public authority", but in many places still prevailed "self-help", as a form of dispute resolution that also had a "criminal" character. In the case of an attack on a family member, the "correction" by self-help was carried out by the same reciprocal attack directly on the perpetrator or a member of his family, applying the rule "eye for eye, tooth for tooth". However, if the person (or his family members) who was attacked did not have the opportunity to "rectify" the act, it could have remained unpunished. So, the "power theory" was applied: everyone had as many rights as much power he had. Such a private-law nature of the dealing with "criminal law" issues can be seen not only in the period before the formation of the state units, but it was present also a few centuries later, after the formation of the first state units.

The gradual development of the medieval state units results in the release of the above-described links in the social structure of the population. The monarch is still at the head of the state, but important members of the aristocracy gradually acquire the majority of the powers over the territory entrusted to them (firstly for life, later hereditary). Thus, alongside the still existing (but above all formal) powers of the sovereign, the judicial power of the aristocracy begins to coexist upon the subjects settled on their property. Another aspect that significantly affected "criminal law" relations was the adoption of the Christian way of life. Although Christianity was accepted in most countries already in the early or high Middle Ages, it is not correct to assume that people have changed their way of life immediately after the adoption of Christianity. 
Such changes can be seen more strongly in the late Middle Ages. It is with the gradual acceptance of the Christian way of life that "humanization of the criminal law" occurs. Under the term "Humanization of Criminal Law" in the Middle Ages, we cannot represent what we understand at present. In the period in question, this "humanization" was carried out rather in the sense that the resolution of disputes, which were originally predominantly private in law, and sanctioning was performed from the position of the public authority. Similarly, the original character of relatively tough "sanctions" has gradually been mitigated - especially as a result of the Church's influence. The originally crippling punishments, even for the less dangerous "crimes", could be replaced by Church repentance or fasting. The character of "criminal law" as a whole, however, despite the gradual mitigating tendencies, remains, from the point of view of the current outlook, overwhelmingly cruel.

For the purpose of this work, it is also important to know what punishments were executed in the contemporary law. Most often these were corporal and crippling punishments. These have been successively replaced by milder forms of punishment or by the imposition of Church fasting or repentance as a result of the Church's action. Although such an alternation of the form of punishment has been documented in our history already in the period of existence of Great Moravia, legitimate discussions are being held among the historians of law, whether such a change was really and rigorously implemented, or such "regulation" on the mitigation of the sentence remained only the will of the highest representatives of the ecclesiastical administration of the Great Moravian period.

The corporal and crippling punishments were gradually "complemented by penalties affecting the property of the" perpetrator of the offense and his family and degrading sentences. At this point, it should be noted that in the past there was no individual ownership in our understanding. Property (especially real-estate) was owned by the family as a whole. Thus, it was not possible to affect only the property of the perpetrator. At the same time, there was a sanction not only for the perpetrator, but his "family" could also have been "punished". Even from the late Middle Ages, it has been repeatedly proven that, for instance, for an attack on the sovereign or his close person, not only by the perpetrator himself was executed, but also members of his family. The 
abovementioned collective punishment of also the offender's family was, in the contemporary sense, justified by, among other things, as the preventive action of the family in preventing the commission of "criminal activity" on the individual, as well as the psychological effect of the perpetrator's fear that the "offense" will be also sustained by his family.

Compared to the structure and form of punishments imposed in the New Age, it is interesting that in the period under our review there was practically no "custodial sentence" in its later understanding. Although we have a lot of evidence of the existence of "dungeons", "jails," or "oubliettes" (for the sake of simplicity we will use only the term "jail" in the text) already from the Middle Ages, they did not serve primarily to "imprisonment". The person who was placed in the prison was interned there in particular to prevent him from escaping. In a jail, the person "waited" for "judgment" in his case. After the delivery of a "judgment", the person was executed, physically punished, sent to exile, sold to slavery (which in our territory existed until the 12th century), or degrading sentences was imposed. It was rare to impose a "prison sentence" in the early or high period of the Middle Ages (the contemporary law did not even recognise such term).

Most of the jails in the Middle Ages were "private in nature": they were "established" based on the sovereign's order (later based on the aristocracy order) for the needs of the "criminal process" against the perpetrators of "crimes" in their "estates". Even the word "established" in the preceding sentence may be striking because it was not a special building or even a separate institutional unit (as it is preserved in a later period), but it was just a few rooms that were part of a castle or military base. Medieval jails reflected the primary need to prevent a person from escaping "justice". In general, there were no special facilities for the execution of this institute, but the premises in existing buildings were used: cellars, warehouses, towers, or even an ordinary excavated pit that was covered by a lattice. Any space that might have been supposed to prevent a person from escape could be used as a jail. These premises did not need to meet any lighting, ventilation or minimal requirements for one prisoner. The people here, because of the lack of legal timeframes within which their case should be resolved, could exist under harsh conditions directly affecting their lives or health for years. 
Only at the turn of the Middle Ages and the New Age, "criminal law" is slowly gaining a more public character. This change is due to slow reflecting changes in the view on the state: the state is no longer conceived as the private property of the ruler (as in the early-feudal period); and almost exclusive arbitrariness of the aristocracy in the management of the country allocated to them to administer (which was characteristic during the period of feudal fragmentation, to a certain extent even during the era of the monarchy of the Estates) was also gradually restricted. Criminal law has slowly acquired the general contours of the public law belonging sector. The original self-help of the parties to the dispute, or discretion of the aristocrat, was increasingly replaced by the provisions of criminal procedural law. (The provisions of the substantive criminal law can also be found in the old law, which we found to have the character of private law, but the implementation of these standards was still in "private hands".)

Although the ideas of the "dignity of the people" (called in today's language) in philosophy emerge from the Renaissance period, they were very slow to be incorporated into the "execution of imprisonment". Only in the period of Humanism will the thoughts be heard that even with the perpetrators of crimes it must be handled at least as dignified as possible, and the changes are still only slow. Only in Modern Times can we see in practice the changes in imposition of penalties: also imposition of "punishment of imprisonment" started to be included in the original forms of punishment to a greater extent. From the original institute, which originally had the character of "detention," one of the forms of punishment is formed.

During this period, a gradual change in the character of "facilities for the execution of a prison sentence" can also be observed. The original jails, which were only a few rooms that were part of another object, changed to separate objects, which also had their own institutional character. It was not common to build new 'prison facilities', most often only older buildings, such as abandoned military bases or unused castles were adjusted. In the seaside countries, even in the Modern Times, for example, ships were used that sometimes stood in the harbour for a year, and in which the convicts were placed, and only after the ships had been filled the convicts were taken to the overseas colonies, where the convicts could be placed in the prisons built there or liberated to "colonize" the overseas countries in such ways. 
Private prisons still existed in the 19th century in several European countries. To their disappearance and the inauguration of state prisons led the claims, for example, stated by English-leftist libertarian Jeremy Bentham (Paul Johnson also called him the spiritual father of the Gulags) that the state would provide correction of prisoners better than the private sector. Today, such categorical claim can be considered as very bold.

Despite the fact that the new "prison facilities" did not meet nearly any standards imposed on such facilities currently, it can be said that there was a significant change in the "prison" system. These facilities are predominantly of the nature of the institutions established by the state. In the given period, in the area of criminal law, both substantive and procedural, public law character prevails, which, at least to the minimum extent possible, indirectly could have eliminated purely private interests in the management of these facilities. With the gradual development of the criminal law science, from which also criminology, criminalistics, penology, etc. started to separate, firstly theoretically, the impact of the "prison facilities" on the persons in these facilities started to be examined, and then the results of this research were also applied in practice.

\section{Conclusion}

Although the change in the criminal law consisting in its transformation into the legal sector having the character of public law, as well as the change in the "prison facilities" consisting in their "deprivatization" is considered from the historical point of view to be correct, it is not appropriate to consider this process historically completed, and at the same time it is not necessary at this time to reject any privatization in the area of criminal law. Even the modern system of prison facilities, which has existed for several centuries, has undergone serious changes. The change in the social conditions that are ongoing and will go on in the future also requires a change in the law as such, not excluding the criminal law.

In practice, some countries already have knowledge of the functioning of private facilities for serving prison sentences. For the conditions of the Slovak Republic, there is no deeper research to implement this knowledge in practice. Thus, there is room for investigators of the grant project Privatization 
of Criminal Law - the substantive, procedural, criminological, organizational and technical aspects to analyse the findings of history as well as findings from the practical realization of private facilities for the execution of custodial sentences in the broadest possible social, legal or economic contexts, and subsequently recommend (or did not recommend) the application of certain elements of such a system to our law.

\section{References:}

Beňa, J. - Gábriš, T. (2006) Dejiny práva na Slovensku (do roku 1918). Bratislava: Univerzita Komenského, 2016. ISBN 9788071603917.

Beňko, J. et al. (1998) Dokumenty slovenskej národnej identity a štátnosti II. Bratislava: Dom slovenskej literatúry, 1998. ISBN 8088878489.

Ferenčíková, S. (2011) Vybrané ustanovenia všeobecnej časti trestného zákona modifikujúce trestné sadzby trestu odňatia slobody. In: Pojem a účel sankcií v slovenskom trestnom práve : zborník vedeckých prác. Košice : Vysoká škola bezpečnostného manažmentu. ISBN 9788089282739.

Ferenčíková, S. (2016) Retroaktivita v trestnom práve. In: Nové trendy v práve 1. Banská Bystrica: Vydavatel'stvo Univerzity Mateja Bela - Belianum. pp. 39-50. ISBN 9788055711034.

Ferenčíková, S. (2016) Uznávanie a výkon cudzích rozhodnutí v kontexte podmienok výkonu detencie. In: Štát a právo : vedecko-teoretický časopis pre otázky vedy o štáte a práve v Slovenskej republike. 2016, Vol. 3, No. 1, pp. 81-87. ISSN 1339-7753.

Gábriš, T. - Jáger, R. (2015) Vlastnícke právo a majetkové vztahy na Velkej Morave. In: Historia et Theoria Iuris (vedecký časopis). Vol.7.No.1/2015.ISSN 1338-0133.

Gábriš, T. - Jáger, R. (2016) Najstaršie právo na Slovensku? Pokus o rekonštrukciu predcyrilo metodského normatívneho systému. Bratislava: Wolters Kluwer. ISBN 9788081685071.

Jáger, R. (2014) Existovalo otroctvo aj na území dnešného Slovenska? In: Ako sa nestat obetou obchodovania s lud’mi? Hladáme riešenie. Banská Bystrica : Inštitút kriminologických štúdií. ISBN 9788055706870.

Jáger, R. (2016) Lingvisticko-etymologická analýza najstarších termínov rodinnoprávnych vzţahov v západo-slovanskom jazykovom prostredí. In: Štát a právo, č.1, roč. 2. 2016, pp. 88-129. ISSN 1339-7753.

Lysý, M. (2013)„Cuiuscumque nationis homines, Saxones videlicet, Hungarii, Sclaui seu alii." Odraz etnicity v normách a úradných dokumentoch stredovekého Uhorska. In Historický ćasopis, Vol. 61, 3/2013. ISSN 0018-2575. 
Lysý, M. (2014) Moravania, Mojmírovci a Franská ríša. Štúdie k etnogenéze, politickým inštitúciám a ústavnému zriadeniu na území Slovenska vo včasnom stredoveku. Bratislava: Atticum. ISBN 9788097138141.

Lysý, M. (2015) I Svätopluk zaslúžil sa o slovenský štát“. Používanie stredovekých symbolov v 20. a 21. storočí. In Historický časopis, Vol. 63, No. 2 ,2015, pp. 333-345. ISSN 0018-2575.

Mičková, Z. (2015). Lingua Latina semper viva in iure. Historia et theoria iuris Vol. 7, Issue 2, pp. 30 - 37. ISSN 1338-0753.

Mosný, P. - Hubenák, L. (2005) Dejiny štátu a práva na Slovensku. Košice: Univerzita Pavla Jozefa Šafárika. ISBN 9788089346028.

Mosný, P. - Laclaviková, M. (2009) History of state and law on the territory of Slovakia I. From ancient times till 1848. Plzeň: Aleš Čeněk, s.r.o. ISBN 9788073802219.

Mosný, P. - Laclaviková, M. (2010) Dejiny štátu a práva na území Slovenska I. od najstarších čias do roku 1848.Šamorín: Heuréka. ISBN 9788081683268.

Steinhubel, J. (2012) Bratislavský komitát. In : Historický časopis, Vol. 2, 2012, pp. 191-214. ISSN 0018-2575.

Švecová, A. - Gábriš, T. (2009) Dejiny štátu, správy a súdnictva na Slovensku. Plzeň: Aleš Čeněk, s.r.o., Bratislava: Atticum. ISBN 9788073801618.

Turošík, M. (2013) Roman Law. Banská Bystrica: UMB, 2013.

Vyšný, P., Puchovský, J. and Šošková, I. (2013). Svetové dejiny štátu a práva. Trnava: Typy Universitatis TyrnaViensis. ISBN 9788056800232.

This article is the output of the grant project APVV-16-0362 Privatization of Criminal Law - the substantive, procedural, criminological, organizational and technical aspects. 